\title{
Faith and Wisdom Based Education
}

\author{
Susanto \\ \{susanto280266@gmail.com\} \\ Department of Biology Education, Faculty of Teacher Training and \\ Education, Universitas Muhammadiyah Purwokerto
}

\begin{abstract}
Humans are aware that they are different from other species in terms of knowledge since they believe they are special and chosen beings. Humans are reflections of the ruh inside them, which has the ability to will and choose. According to Asy'arie, the aim of religion on Earth is to communicate God's sacred messages. The most essential factor, among others, is faith, which leads to grace, happiness, and release. In today's academic environment, scientific progress is bringing humanity closer to dehumanization symptoms, and possibly the potential of changing humanity's nature. As a result, education needs a foundation of intelligence and faith. If we are in confined areas, we will feel stressed and burdened. Descartes' statement cogito ergo sum (I think thus I exist, I exist thus I think) led to the establishment of Rationalism on Epistemology. As a result, the human mind, in general, is short-sighted and tends to think negatively, giving up before trying, losing before fighting, and fearing before something happens. The result of these typical human brains is that young people are less likely to attend college as a result of ineffective education and difficult job search after graduation. I get an agony, with the majority of them weeping for far too long since I regard it as a disaster, making it difficult to rise again. They are greedy if given the opportunity because they do not think Allah SWT would return to them. Haught and Peters use science and religious encounter to demonstrate the optimist character. The most important principle of all Islamic thinking, Tawheed, serves as the cornerstone for science and religious integration in education. As a result, humanity requires a faith-based and wisdom-based education. Indeed, as Allah's characteristic The Most Broad (al-Waasi'), Allah SWT has given humans fitrah to have a broad perspective. But that fitrah had already vanished. That fitrah has been covered by alwahn illnesses (passion for the world and fear of death). We must resurrect. We must always project a good attitude, profound thought, vast knowledge, and wisdom.
\end{abstract}

Key Word: Faith, Wisdom Based Education, Symptoms of Dehumanization.

\section{Introduction}

If we are in a small place, we will feel pressured and burdened. However, if we were in open places, we would feel more free and light. Descartes' cogito ergo sum (I think thus I exist, I exist thus I think) led to the establishment of Rationalism on Epistemology [5]. As a result, most people are short-sighted and don't think optimistically, giving up before trying, losing before fighting, and fearing before something happens. These typical human thoughts are as follows: young people are hesitant to attend college because they believe it will be worthless and difficult to get work once they have finished. I am subjected to an agony, with the majority of them crying for far too long because I regard it as a disaster, making it difficult to recover. With scientific and religious interaction, Haught (2004) and Peters (2006) demonstrate the 
optimist tendency [2,7]. The most important premise of all Islamic thinking, Tawheed [3], serves as the cornerstone for science and religious integration in education. As a result, humanity requires a faith-based and wisdom-based education. Indeed, as Allah's characteristic The Most Broad (al-Waasi'), Allah SWT has given humans fitrah to have a broad perspective. But that fitrah had already vanished. That fitrah has been covered by al-wahn illnesses (passion for the world and fear of death). We must resurrect. We must always project a good attitude, profound thought, vast knowledge, and wisdom.

\section{Literature}

Understanding a wide range of topics demonstrates deep thought and extensive understanding, and so cultivates wisdom. As Rasulullah SAW has previously proven as our role model, such things will improve our lives. He has previously given lessons on how to deal with various types of individuals. "Oh Rasulullah, what is the most prime deeds?" he questioned one of his associates, according to Bukhari. "Faith in Allah and His Rasul," he said. "What's next?" they inquired again, and he responded, "Fight in Allah's methods." They then inquired again, "And what's next?" he replied, "Mabrur Hajj." However, when given the same subject by other friends, he responded differently than previously.

\section{Result and Discussion}

The ruh, a particular gift from Allah SWT, has been given to people to glorify them. Humans have the power to engage with the invisible (metaphysical) reality because they have ruh (ability). In contrast to the world of animals. They can only perceive what's going on around them. Humans are able to see with this talent (Tasha our). Humans have broad and profound behaviors due to their thinking (fikrah) orientation (ittijah). Humans can differentiate between good and bad, right and wrong, halal and haram, if the aforesaid skills are founded on religion. This is referred to as furqon. Assume it isn't founded on faith. In that scenario, individuals would be drawn into a life of jahiliyyah (darkness).

Humans are aware that they are different from other species in terms of knowledge since they believe they are special and chosen beings. Humans are a reflection of the ruh inside them, which has the ability to choose and will [6]. According to Asy'arie (2006), religion on earth serves the vital function of communicating God's holy words; the most significant aspect is faith, which leads to grace, happiness, and emancipation [1]. In today's academic environment, scientific progress is bringing humanity closer to dehumanization symptoms, and even the potential of changing humanity's nature [9]. As a result, education needs a foundation of intelligence and faith.

Emil Brunner [8] states that a decent human being always does what God desires at any given time. As a result, when people are freed from their ruhani and separated from their Lord, they will become animals that dwell in confinement. It is important to take the following specific measures in order for humanity to return to the integrity of their soul, body, and wide wisdom, it is necessary to take the following concrete steps:

a. Humans must understand that they are merely a little portion of the cosmos (dots). Humans will never be able to comprehend the scope of His creation, His kindness, knowledge, 
mercy, and forgiveness. Humans should not arrange themselves in their shells like frogs. Humans should continue to explore and learn.

QS. Ar Rahman (55) : 33

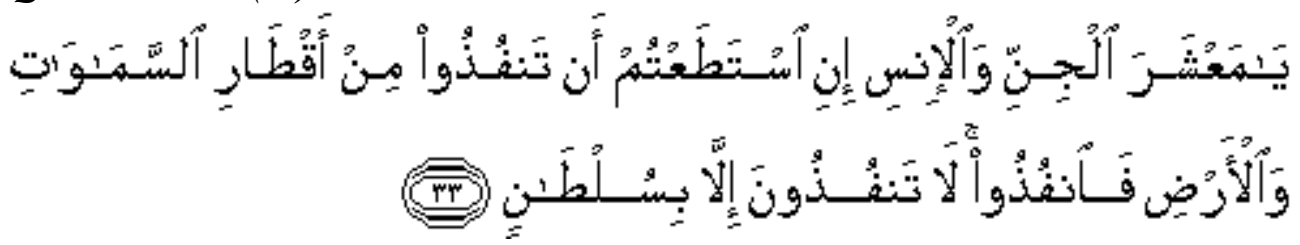

Meaning: "O company of jinn and mankind, if you are able to pass beyond the regions of the heavens and the earth, then pass. You will not pass except by authority."

b. Humans must understand that their existence in this planet has a purpose. Allah SWT, the Supreme Being, is the one who brings it. From conception until birth, the fetus develops into a newborn, toddler, teenager, adult, and senior citizen. Man must surrender to his Creator's phenomena.

QS. Al Baqarah (2) : 28

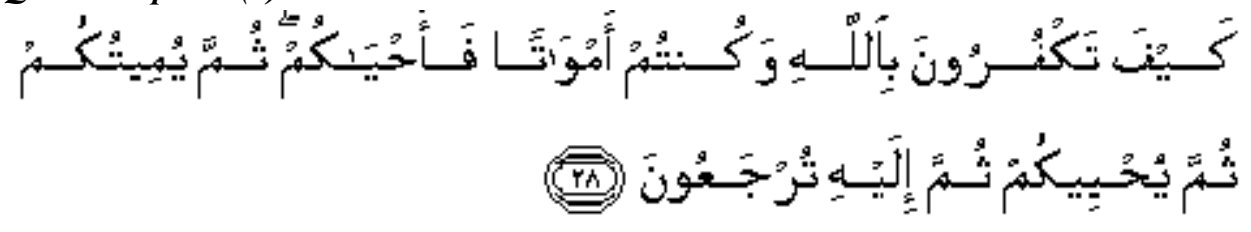

Meaning: "How can you disbelieve in Allah when you were lifeless and He brought you to life; then He will cause you to die, then He will bring you [back] to life, and then to Him you will be returned?"

c. Humans must always study the nafsiyah (spiritual) passages that state that humans are made up of both physical and spiritual components. A reason for humans to live this life by meeting their bodily and spiritual requirements in a holistic and balanced way.

QS. Shaad (38) : 71-72

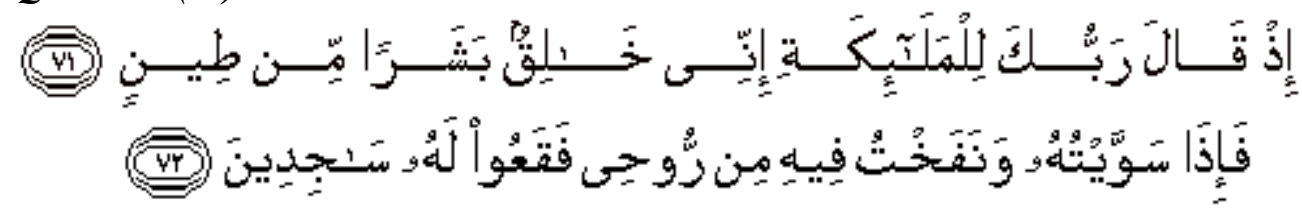

Meaning: "[So mention] when your Lord said to the angels, "Indeed, I am going to create a human being from clay. So when I have proportioned him and breathed into him of My [created] soul, then fall to him in prostration."

d. Because human raw materials are precious, their presence in this world is not just a joke but carries a noble life mission.

QS. Al Mu'minun (23): 115-116

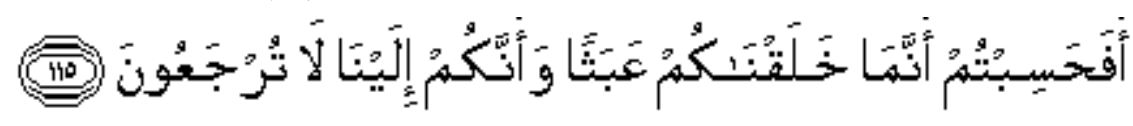




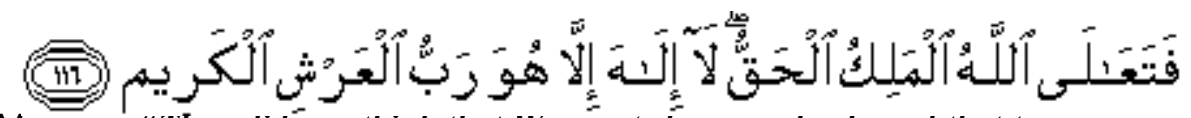

Meaning: "Then did you think that We created you uselessly and that to us you would not be returned?" So exalted is Allah, the Sovereign, the Truth; there is no deity except Him, Lord of the Noble Throne."

\section{QS. Adz-Dzaariyaat (51) : 56}

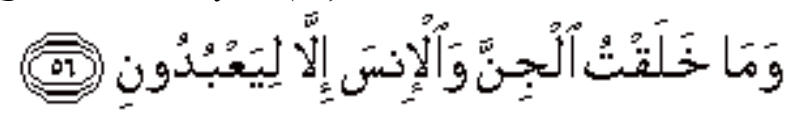

Meaning: “And I did not create the jinn and mankind except to worship Me.”

Humans must heed Allah SWT's signs in order to be successful in wandering in the world (rihyatul hayah) and secure in the hereafter, because He is the one who provides life and knows its mysteries.

QS. Al Baqarah (2) : 38-39

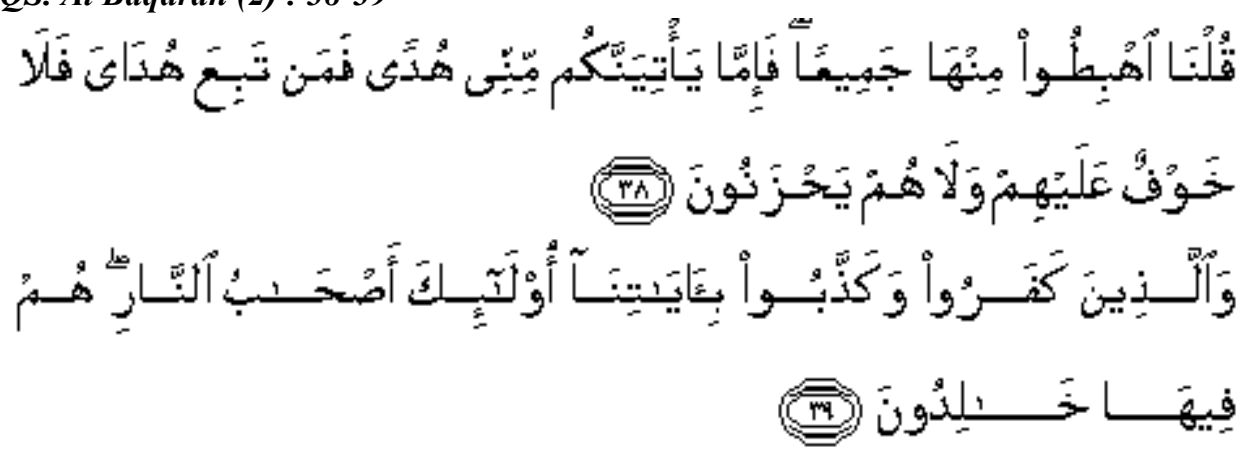

Meaning: "We said, "Go down from it, all of you. And when guidance comes to you from Me, whoever follows My guidance - there will be no fear concerning them, nor will they grieve. And those who disbelieve and deny Our signs - those will be companions of the Fire; they will abide therein eternally."

e. Humans must understand that the end outcome of this world's exam is either an award (pass) and entry into His paradise or a failure and entry into His damnation. How unjust is Allah SWT if there is no compensation? Humans who obey Allah SWT differ from those who disobey Him. A person's life will terminate in accordance with his or her worldly practices. Humans who used to sin would perish in su'ul Khaimah, whereas those who used to obey Him will perish in bustle Khaimah. As a result, humans must choose and choose their behaviors with care.

f. Humans must often look at their past lives as lessons and bridges to success in the future. Humans need to study history more carefully so that they do not fall into the same hole. 
QS. Ali Imran (3): 137

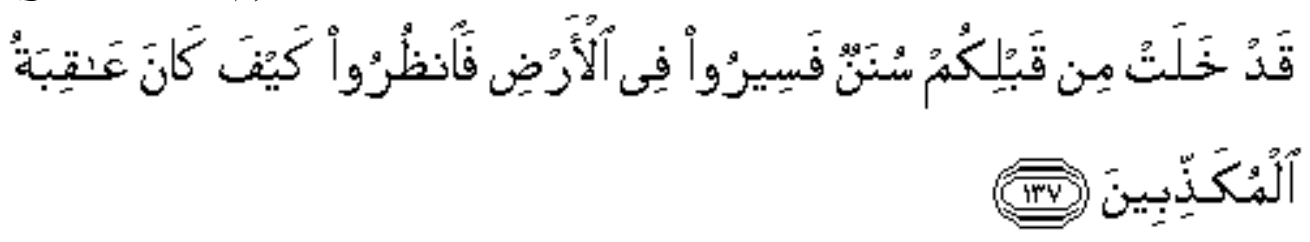

Meaning: "Similar situations [as yours] have passed on before you, so proceed throughout the earth and observe how was the end of those who denied."

g. A human being's mind's breadth of understanding and perspectives is measured by his ability to successfully answer five fundamental questions: (1) Who is he, exactly? (2) How does one show himself to the rest of the world? (3) What is his purpose in life? (4) What should he do for the rest of his life? (5) Where will he go after living in this world? Humans will face a crisis of purpose in life if the five fundamental issues above cannot be addressed accurately and well in a way that satisfies the head and emotions (barrenness and shock of life in this world).

h. There are billions of planets and stars, each with its own unique features. There are huge areas, seas, woods, mountains, and other natural features on the planet where humans dwell. Minerals, water, oxygen, and carbon dioxide are among the components required for the life of living organisms such as plants, animals, and people in nature. The universe, according to modern scientists of all disciplines, is a source of intelligence (Russell intelligence). A sensation of wonder inspires astonishment at reality and the dazzling light that illuminates it, resulting in great works of science and art. Einstein himself claimed that a clash between science and religion is unthinkable [4].

\section{Conclusion}

Humans are also placed in diverse natural environments, resulting in variations in traditions, habits, and culture. Extensive in His Power and Knowledge, Extensive in His Mercy, and Extensive in His Forgiveness is Allah the Exalted.

\section{QS. Al An'aam (6): 80}

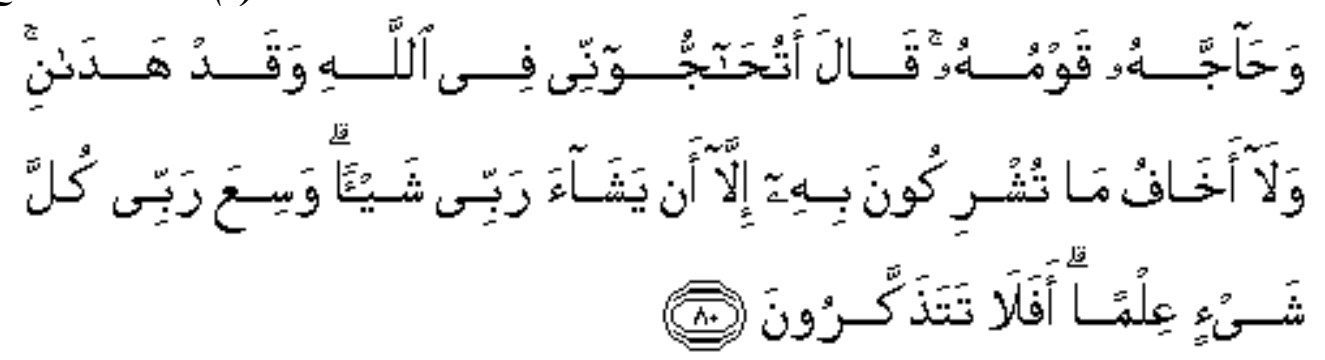


Meaning: "His people also disagreed with him. ", he explained "Do you disagree with me about Allah when He has directed me? And I have no fear of whatever you connect with Him [and will not be hurt] until my Lord wills it. Will you forget that My Lord includes all things in knowledge?"

QS. An-Najm (53) : 32

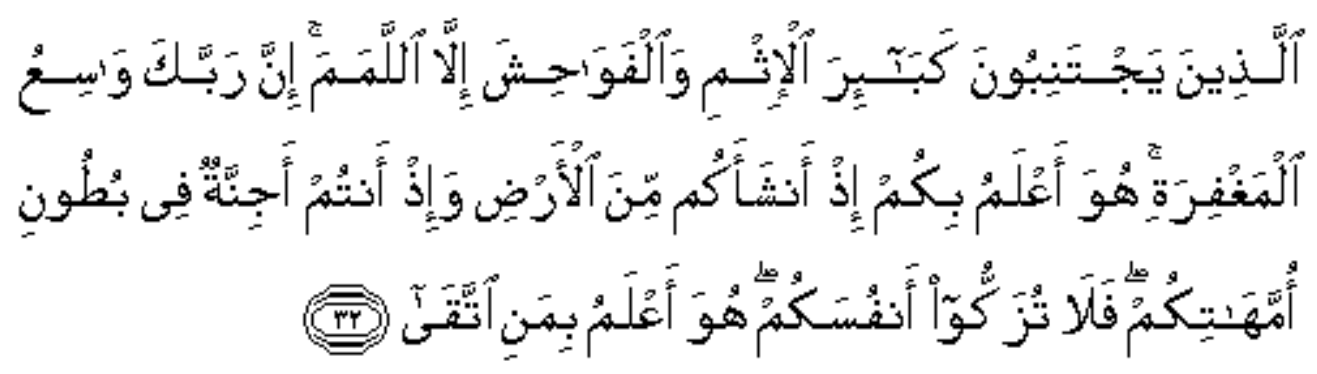

Meaning: "Those who abstain from big crimes and immoralities, committing only minor ones." Your Lord, indeed, is kind in his forgiveness. He knew the most about you when He created you from the ground and when you were fetuses in your mothers' wombs. So don't pretend to be pure; He is the most aware of those who fear Him."

QS. Al Baqaarah (2) : 115

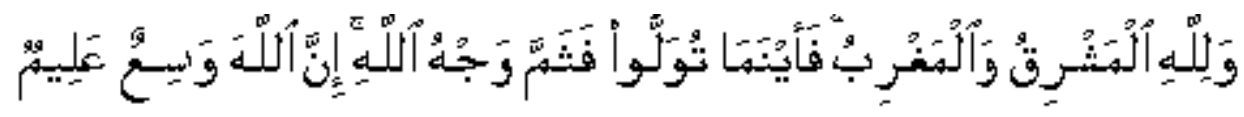

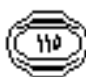

Meaning: "And the east and the west belong to Allah. So the Face of Allah can be found everywhere you turn. Indeed, Allah is all-knowing and all-encompassing."

QS. Ali Imran (3): 190

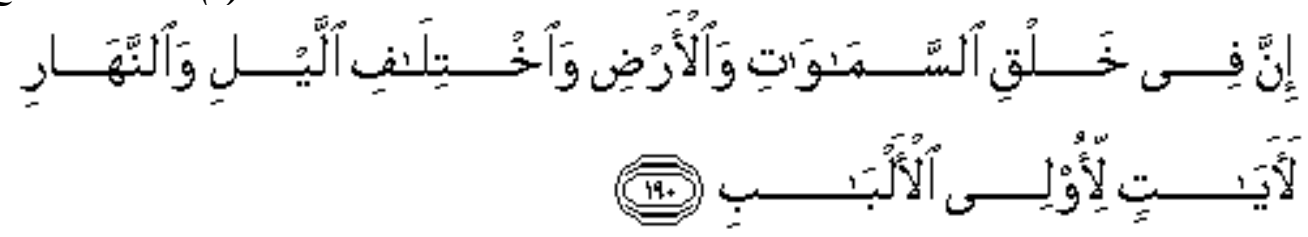

Meaning: "Indeed, indications for those who understand may be seen in the creation of the heavens and the earth, as well as the alternating of night and day"

QS. Adz Dzaariyaat (51): 20-21

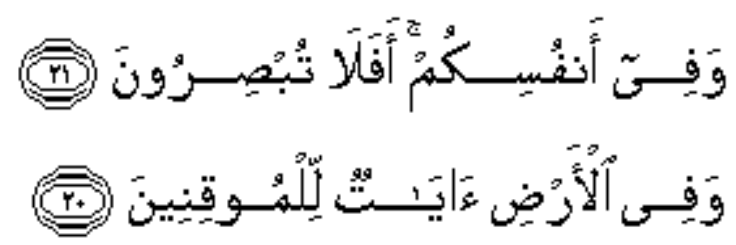

Meaning: "And on the earth are signs for the certain [in faith] And in yourselves. Then will you not see?" 


\section{References}

[1] Asy'arie, Musa. 2006. Religion for Poverty Liberation on Science, Religion Ethics: Uncover Science and Human Veil. Yogyakarta: CRCS Postgraduate program, Gadjah Mada University. ISBN: 97925-5285-5.

[2] Haught, John F. 2004. Science and Religion Encounter: From Conflict to Dialogue. Bandung: Mizan Pustaka. ISBN: 979-433-371-9.

[3] Kartanegara, Mulyadi. 2005. Science Integration: A Holistic Reconstruction. Bandung: Arasy Mizan Pustaka. ISBN 979-3551-11-9.

[4] Leahy, Louis. 2002. Human Horizon. Yogyakarta: Publisher Kanisius. ISBN: 979-21-0559-1.

[5] Muslih, Muhammad. 2004. Science Philosophy: Study Upon Basic Assumption, Paradigm, and Scientific Theory Construction. Yogyakarta: Blukar. ISBN: 979-3494-05-0.

[6] Muthahhari, Murtadha. 2002. Humankind and Nature: Islamic Concept About Universe. Jakarta: Lentera. ISBN: 979-3018-12-7.

[7] Peter, Ted. 2006. Science and Faith: From War toward Alignment in God, Nature, Human: Religion and Science Perspective. Bandung: Mizan Pustaka. ISBN: 979-433-409-X.

[8] Rachels, James. 2004. Morale Philosophy. Yogyakarta: Publisher Kanisius. ISBN: 979-21-0949-8.

[9] Suriasumantri, Jujun S. 2005. Science Philosiphy a Popular Introduction. Jakarta:Pustaka Sinar Harapan. 